\title{
LITERALIDADE E METÁFORA NA FILOSOFIA DE GILLES DELEUZE: UMA VIA BERGSONIANA ${ }^{1}$
}

Christian Fernando Ribeiro Guimarães Vinci (USP) $)^{2}$

christian.guimaraes.vinci@gmail.com

Resumo: Este artigo objetiva pensar o debate envolvendo a questão da literalidade na obra de Gilles Deleuze, mormente naquela escrita em parceria com Félix Guattari, a partir de um recuo pelo pensamento do filósofo Henri Bergson. Apresentada como um modo singular de operar com a escrita, a literalidade deleuze-guattariana exigiria que determinadas formulações, mormente aquelas de teor imagético fossem lidas ao pé da letra (a la lettre) ao invés de interpretadas como metáforas. Tendo adentrado em nosso país por meio do dossiê Entre Deleuze e a Educação, publicado em 2005 no periódico Educação \& Sociedade, a questão da literalidade fomentou uma discussão acalorada, nomeadamente no campo educacional - dado o fato de um dos participantes, François Zourabichvili, propor uma pretensa teoria de ensino deleuzeana a partir dessa noção. Longe de querer encerrar tal debate, almejamos pensá-lo sob a égide do pensamento bergsoniano, a fim de propor um escape do binarismo estabelecido.

Palavras-chave: Gilles Deleuze; Literalidade; Metáfora; Henri Bergson.

\section{INTRODUÇÃO}

Gilles Deleuze e Félix Guattari, ao escreverem o primeiro tomo do díptico Capitalismo $\mathcal{E}$ Esquizofrenia, O Anti-Édipo,

\footnotetext{
${ }^{1}$ Recebido em: 12-09-2016 / Aprovado em: 20-02-2018 / Publicado on-line em: 07-08-2018.

${ }^{2}$ Christian Fernando Ribeiro Guimarães Vinci é Doutorando pela Faculdade de Educação da Universidade de São Paulo, São Paulo, SP, Brasil. Bosista FAPESP.
} 
não se furtaram em dimensionar as prováveis polêmicas que tal obra acenderia. Nesta, conforme introduziam o leitor à segunda tarefa positiva da esquizoanálise, os autores chegaram a argumentar:

Aqueles que nos leram até aqui teriam talvez muitas censuras a nos fazer: acreditar em demasia nas puras potencialidades da arte e até da ciência; negar ou minimizar o papel das classes e da luta de classes; militar por um irracionalismo do desejo; identificar o revolucionário com o esquizo; cair em todas estas conhecidas armadilhas, demasiado conhecidas. Isto seria uma má leitura - e não sabemos o que é pior: se uma má leitura ou se leitura nenhuma. (Deleuze; Guattari, 2010, p. 502. Grifos nossos).

Essa percepção de uma má leitura seria ratificada anos depois, conforme prefácio escrito pelos autores para a edição italiana de Mil Platôs, publicada em 1987. Para Deleuze e Guattari (2000), houve uma espécie de fracasso mais profundo do livro precedente, não obstante o sucesso editorial alcançado pelo mesmo, decorrência de interpretações equivocadas de seu aparato conceitual. A fim de evitar malogro similar com a nova publicação, os autores cercaram-se de cautelas, chegando a exigir de seus leitores, em diversos momentos da obra, uma maior prudência ao lidar com certos enunciados ${ }^{3}$. Os cuidados adotados não evitaram o surgimento de novas e intensas polêmicas, apesar da baixa

\footnotetext{
${ }^{3}$ As experimentações linguageiras e conceituais de Mil Platôs buscaram apresentar, como regra imanente, uma dose de prudência: "Mas por que este desfile lúgubre de corpos costurados, vitrificados, catatonizados, aspirados, posto que o CsO é também plano de alegria, de êxtase, de dança? Então, por que estes exemplos? Por que é necessário passar por eles? Corpos esvaziados em lugar de plenos. Que aconteceu? Você agiu com a prudência necessária? Não digo sabedoria, mas prudência como dose, como regra imanente à experimentação: injeções de prudência. Muitos são derrotados nesta batalha" (Deleuze; Guattari, 2007, p. 11. Grifos nossos). Para uma discussão sobre a prudência em Capitalismo $\mathcal{E}$ Esquizofrenia, remetemos o leitor à (referência omitida).
} 
receptividade do último volume de Capitalismo $\mathcal{E}$ Esquizofrenia (Deleuze; Guattari, 2000).

Os modos como os tomos integrantes da coleção supramencionada foram lidos e seus conceitos apropriados renderam e rendem muitas controvérsias ${ }^{4}$. Dentre estas, ganhou consistência entre nós aquela envolvendo a questão da literalidade. Apresentada como um modo singular de operar com a escrita, a literalidade deleuze-guattariana exigiria que determinadas formulações, mormente aquelas de teor imagético - tais como "o próprio cérebro é muito mais uma erva do que uma árvore" (Deleuze; Guattari, 2000, p. 25) ou "há tão somente máquinas em toda parte" (Deleuze; Guattari, 2010, p.11) -, fossem lidas ao pé da letra (a la lettre) ao invés de interpretadas como metáforas ${ }^{5}$.

Tendo adentrado em nosso país por meio do dossiê Entre Deleuze e a Educação, publicado em 2005 no periódico Educação $\mathcal{F}$ Sociedade, a questão da literalidade fomentou uma discussão acalorada, nomeadamente no campo educacional. François Zourabichvili (2005) iniciador do debate, apresentou uma densa análise da literalidade e, a partir desta, vislumbrou uma pretensa teoria do ensino deleuzeana. Tomaz Tadeu (2005) e Peter Pál Pelbart (2005), foram in-

\footnotetext{
${ }^{4} \mathrm{Um}$ exemplo recente advém dos textos oriundos do seminário Ateliers sur l'anti-oedipe (Cornibert; Goddard, 2008), os quais apresentam uma pluralidade de leituras e interpretações, muitas vezes antagônicas, da obra O Anti-Édipo. As polêmicas impressas nesses escritos dão mostras da dificuldade em se operar com o aparato conceitual de Deleuze e Guattari, uma vez que este possibilitaria formas diversas de apropriação e aplicação. O seminário em questão, ademais, apenas deu prosseguimento a um debate iniciado anos antes, em 2002, no dossiê L'effect Deleuze publicado no periódico Le Magazine Littéraire, envolvendo os deleuzeanos inventivos e os deleuzeanos não-inventivos. Para um panorama dessa polêmica ver (referência omitida).

${ }^{5}$ Como o nota François Zourabichvili (2005), construções como "isto não é uma metáfora" ou "isto deve ser lido literalmente" são uma espécie de ritornelo na filosofia de Deleuze, estando presente em variados momentos de sua obra, escrita ou não em parceria com Félix Guattari.
} 
cumbidos de discutir o texto apresentado pelo colega francês. Enquanto Pelbart endossou o argumento de Zourabichvili, levando a discussão para searas não-pedagógicas, Tadeu teceu-lhe algumas críticas, já vislumbrando o interesse - e os equívocos - que tal leitura poderia suscitar em muitos pesquisadores da área educacional interessados no pensamento de Deleuze. Descontadas as censuras, Tadeu não deixou de apontar o quão interessante seria um maior aprofundamento dessa questão, a fim de pensarmos as possibilidades de formulação de uma teoria do ensino deleuzeana - objetivo do próprio Tadeu à época (Gandin; Paraskeva; Hypolito, 2002).

Uma espécie de resposta surgiria no ano subsequente, no seminário organizado em França acerca da feitura d'O Anti-Édipo, Zourabichvili (2008) retornaria à essa polêmica, reafirmando sua interpretação da literalidade como uma prática filosófica que envolveria uma crença em outro tipo de escrita/leitura ${ }^{6}$. No Brasil, Anita Costa Malufe (2012; 2015), poetisa e crítica literária, viria engrossar esse debate, argumentando que esse modo de escrita, imanente nos dizeres da autora, seria o único capaz de permitir a Deleuze e Guattari usufruírem de uma prosa poética capaz de instaurar um bloco de devir, este concebido como uma espécie de deslocamento capaz de fomentar uma outra relação, literal e não metafórica, entre os termos constitutivos de um enunciado.

\footnotetext{
${ }^{6}$ François Zourabichvili faleceu em 2006, não chegando a apresentar publicamente sua análise sobre a escrita literal d'O Anti-Édipo no seminário supracitado, ocorrido poucos meses depois de sua morte. Não houve tempo suficiente para que o autor francês elaborasse uma resposta a Tadeu, embora o texto publicado nos anais do evento enseja uma retomada das críticas dirigidas por este.
} 
Ponto pacífico para os autores supracitados, a questão da literalidade em Deleuze passa necessariamente por sua leitura da obra de David Hume, tal qual apresentada em Empirismo e Subjetividade (Deleuze, 2001). A literalidade assentar-se-ia em uma relação singular entre conhecimento e crença, com especial prevalência desta sobre aquela. Contudo, como apontou Tadeu (2005), apoiados apenas nessa relação, não conseguimos explicar convenientemente a prevalência do tom metafórico presente nos escritos deleuzeanos, elaborados ou não em parceria com Guattari.

Adensemos essa problematização relembrando brevemente alguns momentos em que o aporte à metáfora, por parte de Deleuze, não se explica adequadamente pela simples remissão à sua leitura do pensamento de Hume. Como explicar, por exemplo, a afirmação deleuzeana "todo conceito possui em si, virtualmente, um aparelho metafórico" (Deleuze, 1968, p. 300)? E a utilização de metáforas por Friedrich Nietzsche na constituição de sua filosofia, assentada em aforismos e poemas, tal qual constatada por Deleuze (1976)? Ou, ainda, a aceitação, em O que é a Filosofia (Deleuze; Guattari, 1992), de que as figuras metafóricas tendem para os conceitos e vice-versa? Zourabichvili, posteriormente (2011), reconheceria esses distintos momentos e afiançaria a dificuldade em encerrar esse debate, sem, contudo, abandonar a sua posição inicial.

A afinidade dos autores de Mil Platôs com certas figuras de linguagem, sobretudo com a metáfora, parece ser mais complexa do que imaginamos. Afirmar que há uma literalidade na qual devemos acreditar piamente, pois apenas esta possibilitaria o estabelecimento de novas e potentes relações 
entre termos distantes, não parece dar conta, por si só, de sanar essas aporias. $\mathrm{O}$ quanto daquela má leitura vislumbrada por Deleuze-Guattari, não decorreu justamente dessa dificuldade em compreendermos alguns de seus procedimentos escriturais?

Sem intento resolutivo, esse artigo procurará adentrar em tal discussão seguindo um veio outro, sugerindo e sustentando uma abordagem distinta dessa questão. Procuraremos, antes, pensar o papel de figuras de ressonância metafórica na elaboração do discurso filosófico deleuzeguattariano recorrendo, para tanto, ao pensamento de Henri Bergson - autor de extrema importância para o projeto filosófico de Deleuze ${ }^{7}$. Assim, ao invés de pensarmos o debate da literalidade em termos humeanos, ressaltando apenas a exterioridade da relação quanto aos termos que comporta e o imperativo de crermos nas novas relações estabelecidas por Deleuze-Guattari em seus escritos a fim de ultrapassarmos aquilo dado por um enunciado, propomos pensá-lo à luz da crítica bergsoniana aos conceitos generalizantes e a necessidade de comparações e metáforas para explicar aquilo que apenas a razão analítica, assentada em uma linguagem abstrata, não daria conta. Ou, em outros termos, buscar pensar a relação existente entre imagem e conceito. Essa leitura, quiçá, permitirá o fortalecimento de certa interpretação da literalidade como processo de dramatização, tal qual defendido por Malufe $(2012$; 2015).

Por qual razão acreditamos que esse desvio pelo pensa-

\footnotetext{
${ }^{7}$ Para alguns comentadores, toda a obra de Deleuze foi atravessada por um bergsonismo peculiar, ao ponto de suas análises de Nietzsche e Spinoza terem sido realizados a partir de questões postas por sua leitura de Bergson. Para maiores detalhes ver (Alliez, 2000).
} 
mento bergsoniano demonstrar-se-á frutífero para essa discussão? Lembremos que Bergson (2006), prêmio Nobel de literatura, chegou certa vez a proclamar acerca do uso de metáforas:

A intuição, por outro lado, só será comunicada pela inteligência. Ela é mais que ideia; todavia, para se transmitir, precisará cavalgar ideias. Pelo menos se endereçará de preferência às ideias mais concretas, que uma franja de imagens ainda envolve. Comparações e metáforas sugerirão aqui aquilo que não conseguiremos exprimir. Não se tratará de um desvio; nada faremos senão ir direto ao objetivo. Se falássemos constantemente uma linguagem abstrata, pretensamente "científica", não daríamos do espírito mais que a sua imitação pela matéria, pois as ideias abstratas foram extraídas do mundo exterior e implicam sempre uma representação espacial: e, no entanto, acreditaríamos ter analisado o espírito. As ideias abstratas, tomadas em separado, convidar-nos-iam portanto aqui a nos representarmos o espírito com base no modelo da matéria e a pensá-lo por transposição, isto é, no sentido preciso da palavra, por metáfora (p. 45).

Para o autor de $\mathrm{O}$ Pensamento e o Movente, a linguagem abstrata, pretensamente científica, possuiria uma limitação, pois incapaz de exprimir diretamente uma intuição a não ser por meio de representação; não obstante isso, algumas intuições são aquilo que temos de mais próximo, como é o caso da duração tal qual apresentada por Bergson, por serem dadas de maneira imediata ao espírito. A metáfora, nesse caso, capaz de sugerir-nos uma determinada imagem, auxiliar-nos-ia a comunicar aquilo que a linguagem abstrata não o consegue. Tratar-se-ia de um instrumento narrativo capaz de levar-nos "direto ao objetivo". Contudo, a metáfora não pode restar refém da linguagem abstrata, por ainda correr o risco de preservar elementos de ordem representativa. Diante disso, devemos tomar certo cuidado com a utilização da linguagem imagética em filosofia. Metáforas e 
comparações não devem ser tomadas em seu "sentido preciso", mas numa outra chave, devemos partir delas para atingir uma espécie de imagem conceitual, anterior à formulação de um conceito. Bergson arma, a partir dessa tensão entre uma linguagem imagética e uma linguagem abstrata, toda uma crítica à filosofia de seu tempo e renova o fazer filosófico ao trazer ao coração de suas análises a questão da escrita e dos usos de recursos estilísticos em filosofia. Retomar essas análises talvez nos auxilie a situar o debate acerca da literalidade em Deleuze sob outras bases, sem recair nas aporias do simplificado binômio metáfora-literal.

Para tanto, esse artigo navegará por três estratos distintos: em primeiro lugar, apresentaremos um panorama do debate acerca da literalidade; na sequência, retomaremos a discussão bergsoniana acerca da metáfora e da linguagem imagética; e, por fim, procuraremos entrecruzar ambos os estratos a fim de pensarmos as suas implicações para aquela pretensa teoria de ensino deleuzeana vislumbrada por Zourabichvili.

\section{O DEBATE ACERCA DA LITERALIDADE: PODERIA UMA METÁFORA SOAR LITERAL?}

Como compreender a assertiva: "mas o próprio cérebro é muito mais uma erva do que uma árvore" (Deleuze; Guattari, 2000, p. 25)? Tendencialmente, optaríamos por buscar o domínio próprio das principais expressões apresentadas, a fim de extrair a definição comumente aceita dos termos presentes na oração: cérebro, erva e árvore. Feito isto, passaríamos a tentar compreender a relação estabelecida entre estes termos no interior da expressão dada. A metáfora, 
como costumeiramente a utilizamos em nosso dia a dia, nada mais é do que o estabelecimento de uma relação de semelhança entre termos distantes. Tomemos o enunciado "seu rosto era uma lua" como exemplo, mais simples do que aquele proposto por Deleuze-Guattari. "Rosto" e "lua" dizem respeitos a entidades distintas, mas ao os colocarmos em relação, acabamos por transpor as características de um para explicar o outro. Seu rosto era brilhante e redondo como uma lua, quiçá.

Contudo, ao lidarmos com o pensamento de Deleuze e Guattari as coisas se complicam. "O cérebro é muito mais uma erva do que uma árvore”, para os autores, não envolveria qualquer metáfora. São diversos os momentos de Capitalismo $\mathcal{E}$ Esquizofrenia nos quais a leitura metafórica é rechaçada, sendo o início d'O Anti-Édipo aquele mais famoso e polêmico:

Isso funciona em toda a parte: às vezes sem parar, outras vezes descontinuamente. Isso respira, isso aquece, isso come. Isso caga, isso fode. Mas que erro ter dito o isso. Há tão somente máquinas em toda a parte, e sem qualquer metáfora: máquinas de máquinas, com seus acoplamentos, suas conexões. [...] O presidente Schreber sente algo, produz algo, e é capaz de fazer a teoria disso. Algo se produz: efeitos de máquinas e não metáforas (Deleuze; Guattari, 2010, p. 11. Grifos nossos).

O intuito dos autores, como defendem Tadeu (2005) e Malufe (2012), seria substituir a relação metafórica entre termos distantes, representacional por excelência, por uma relação concreta, maquinal no caso em questão. Se "há tão somente máquinas em toda a parte", um efeito sentido por um corpo - ele também máquina - só pode ser produto de uma relação maquínica, envolvendo uma conexão concreta 
de corpos distintos, e deve ser explicada maquinalmente [literalmente], sem qualquer desvio metafórico. O que estaria em jogo nesse argumento, conforme reconhece Zourabichvili $(2008$; 2011), seria a substituição de uma ideia de desejo como representação por aquela de desejo como produção, tese central d'O Anti-Édipo. A metáfora representaria, as máquinas, em contrapartida, conectariam e produziriam. Os enunciados anti-edípicos, por esse motivo, devem funcionar como máquinas, produzir um efeito, e jamais como metáforas. Mas, por qual razão devemos compreender a construção "há tão somente máquinas em toda a parte”, ou similares, literalmente? Por crença, respondernos-iam aqueles defensores da literalidade.

Partindo da compreensão de que as relações são sempre exteriores aos termos envolvidos, portanto não há um domínio próprio a cada termo apresentado em uma construção propositiva, a literalidade implicaria a imanência do sentido e da proposição. Desse modo, não haveria um sentido apriorístico a ser desvendado, mas apenas um a ser experimentado no interior de um determinado enunciado. $\mathrm{O}$ sentido da expressão "o cérebro é muito mais uma erva do que uma árvore", portanto, não deveria ser buscado no nosso conhecimento a priori desses termos, mas no interior da relação proposta por seu enunciador. Contudo, nossa tendência natural ao ouvirmos tal expressão não seria procurarmos relações de similitude, buscando transpor para um termo as características pertencentes a outro? Sim, por esse motivo devemos sempre refazer os argumentos de um autor.

Para Zourabichvili (2005), a crença deve ser compreen- 
dida como sinônimo de fazer: "crer no que o filósofo diz é, pois, fazer com ele o que ele faz quando enuncia, não separar nunca os seus conceitos do desvio, os casos. Isso supõe que o próprio fazer seja enunciado, indicado em palavras" (p. 1312). Portanto, crer que um cérebro é uma erva significaria fazer uma relação inferencial tal qual a fez DeleuzeGuattari. Mas como os autores a fizeram? Afirmando, posteriormente ao enunciado em questão, que não se trata de uma metáfora. Os autores indicam em palavras como ler, portanto, mas a posteriori somente.

A crença deveria possibilitar à escrita literal construir uma outra relação, na qual os termos não possuiriam domínios próprios - tal qual em uma metáfora - a não ser no interior da própria relação proposta pelo enunciado. Essa construção, por sua vez, visar-nos-ia ofertar uma outra experiência, distante daquela consolidada pela doxa. Estaria em jogo, desse modo, a criação de um novo horizonte de inteligibilidade.

Crer que o cérebro é uma erva é um novo horizonte, tanto para a neurologia quanto para a filosofia. Crer não tem nada a ver com formular uma hipótese a propósito de uma essência, cuja revelação se situaria no infinito do processo de conhecimento. Crer é um acontecimento, uma síntese passiva, um ato involuntário, que se confunde com a abertura de um novo campo de inteligibilidade (Zourabichvili, 2005, p. 1317).

Disso segue, para os defensores da literalidade, a importância da leitura deleuzeana do empirismo de Hume, autor inglês em cuja obra Deleuze vislumbrou o estabelecimento de outra relação entre conhecimento e crença, afirmando a preponderância desta sobre aquele. A partir desse lastro, Zourabichvili justifica o intento das construções deleuze- 
guattarianas, a saber: a busca pelo estabelecimento de conexões capazes de abrir nossos sentidos para outros possíveis, quiçá mais potentes. Assim, prossegue Zourabichvili, a recusa da metáfora em prol da literalidade não visaria nada além de transtornar a cópula "É" em "E", a fim de permitir o estabelecimento daquelas conexões outras. A afirmação "o cérebro é muito mais uma erva do que uma árvore", transmutar-se-ia em algo como "o cérebro e uma erva" ${ }^{8}$. Conforme adentramos no aparato conceitual de DeleuzeGuattari, essa crença se fortaleceria ao ponto de se transmutar em hábito.

Como nota Tomaz Tadeu (2005), entretanto, a transmutação de uma partícula atributiva ("É") em partícula conjuntiva ("E"), no limite, tenderia a acabar com toda e qualquer literalidade, uma vez que aboliria o tom metafórico dos escritos de Deleuze-Guattari. Em outros termos, não haveria literalidade a ser explicada ao produzirmos esse deslocamento, e asserções peremptórias como aquela lançada na abertura d'O Anti-Édipo bem como outras tantas, careceriam de funcionalidade. Ou seja, enunciados como "e isto não é uma metáfora" possuem sua razão de ser, lembra-nos Tadeu, pois, ao mesmo tempo em que afirmariam o tom

\footnotetext{
${ }^{8}$ Nesse sentido, poderíamos indagar ainda: ao transformar uma proposição atributiva em uma proposição conjuntiva, não estaria Zourabichvili transmutando o conceito em função? Função, nesse sentido, diria respeito as proposições científicas, apresentadas por Deleuze-Guattari em $\mathrm{O}$ que é a Filosofia? como uma parada da imagem, algo estático e não dinâmico, cujo ponto de referência estaria alhures. Tomemos o exemplo aqui trabalhado. Zourabichvili não nega que Deleuze, ao afirmar que o cérebro é uma erva, estaria preocupado em aproximar o conceito de cérebro de sua discussão acerca do rizoma, contrapondo-o ao modelo arborescente tipicamente representacional. Está em jogo toda uma nova concepção sobre o que significa pensar, cujas bases não estão dadas na proposição analisada, mas encontram-se espaçadas ao longo da obra de Deleuze. Para Deleuze e Guattari (1992): "As funções tiram toda sua potência da referência, seja a estado de coisas, seja a outras proposições: é fatal que a redução do conceito à função o prive de todos seus carácteres próprios, que remetem a uma outra dimensão" (p. 180).
} 
metafórico de uma construção precedente, exigem que o leitor ultrapasse esse dado a fim de compreender qual outra relação está em jogo. Pela leitura de Zourabichvili, a literalidade não comportaria essa possibilidade de reconhecimento de qualquer traço pretensamente metafórico.

Buscando sanar esses pontos obscuros, Zourabichvili (2008) voltaria a defender que Deleuze-Guattari conceberam um novo modo de fazer filosofia, envolvendo uma outra relação com a escrita-leitura. Esse novo modo, contudo, tornar-se-ia compreensível e palatável apenas àqueles conhecedores da lógica inerente ao aparato conceitual dos autores. A afirmação "e isto não é uma metáfora”, por conseguinte, não possuiria realmente qualquer função para aqueles já iniciados na filosofia de Deleuze e Guattari, uma vez que estes teriam um conhecimento prévio da imanência que estaria em jogo em determinadas construções deleuzeguattarianas. A assertiva supracitada, então, possuiria apenas um caráter informativo ou comunicativo, destinado aos leitores neófitos. Poderíamos, assim, afirmar que compreender a conexão estabelecida por Deleuze e Guattari em muitos excertos de sua obra à luz da literalidade, ao menos tal qual a compreende Zourabichvili, implicaria ou no estabelecimento de um intervalo no processo de leitura, decorrente da necessidade em reconstruirmos abstratamente os enunciados deleuze-guattarianos sob um fundo analítico mais amplo, ou, ao contrário e de maneira similar, em um hábito adquirido após longo estudo.

Sem dúvida, após muito lermos Deleuze e Guattari, com suas advertências para que não tomemos suas assertivas como metáforas, tenderemos a recusar as imagens sugeridas por seus enunciados, e, analisando certo excerto à luz 
da filosofia defendida pelos autores, buscaríamos enquadrálo dentro de um quadro teórico ampliado. Essa seria uma premissa presente tanto na análise de Zourabichvili (2008) quanto na de Malufe (2012). Aquele defende que, apenas por meio da compreensão do conceito de imanência, podemos passar a acreditar nas relações estabelecidas por Deleuze-Guattari. Malufe, por sua vez, concorda com o prognóstico de Zourabichvili e prossegue, afirmando a importância dessa compreensão primeira da filosofia deleuzeana e/ou deleuze-guattariana para que seu leitor possa adentrar no fluxo de escrita dos pensadores franceses. Ora, não haveria uma contradição latente entre a experimentação da relação proposta por um enunciado sem qualquer apriorismo e essa necessidade de conhecimento prévio da filosofia de Deleuze-Guattari? A análise, decomposição abstrata daquele fluxo de escrita trazida pelos autores, não tenderia a imobilizar o movimento próprio do texto deleuzeguattariano, aquele fluxo de pensamento tão caro aos autores de Mil Platôs?

Sem dúvida, reconhecemos a necessidade de estabelecermos uma outra relação de leitura com o texto deleuzeguattariano. Mas qual relação seria essa? A de um crente? A de um imitador? O próprio Deleuze ofertou-nos uma enigmática resposta, passível de orientar-nos nessa questão, a saber:

Uma boa maneira de ler hoje em dia, seria tratar um livro como se ouve um disco, como se vê um filme ou uma emissão televisiva, como se recebe uma canção: qualquer tratamento do livro que exija um respeito especial, uma atenção de outro tipo, vem do passado e condena definitivamente o livro. Não há questão alguma de dificuldade nem de compreensão: os conceitos são exatamente como sons, cores ou imagens, são intensidades que lhes convém ou não, que 
passam ou não passam. (Deleuze; Parnet, 2004, p.14).

Ler com uma outra atenção, sem tratamentos especiais, assim poderíamos resumir o que nos diz Deleuze. Mas o que isso significa? Acreditamos que a ânsia pela compreensão, força motriz da análise, comprometeria a escuta do livro, o fluxo narrativo próprio de um escrito. Talvez a metáfora, bem como outras tantas ferramentas típicas de uma linguagem imagética, possibilitar-nos-ia acessar de maneira imediata esse fluxo, desinteressadamente. Afinal, os conceitos, como multiplicidades que são, possuiriam certo lastro imagético (Deleuze; Guattari, 1992). Por esse motivo, afiançamos que a questão da compreensão dos escritos deleuze-guattarianos passaria por uma questão de apreensão do movimento, do fluxo etc., mais do que por uma crença pautada por um entendimento analítico prévio do pensamento desses autores, tal qual defendem os próprios Deleuze-Guattari.

Parece-nos que, para Deleuze e Guattari, a lógica, ou a ânsia analítica, deveria calar-se diante da intensidade própria de um pensamento, pois, só assim o leitor poderia acessar o movimento infinito do pensar, o fluxo de seu monólogo interior, a fim de possibilitar-lhe reconquistar o poder imanente de sua criação. A paradoxal metáfora que não é metáfora, desse modo, prestar-se-ia a essa tarefa: calar a lógica. Anita Costa Malufe $(2012 ; 2015)$ foi a autora que mais aproximou-se dessa concepção, sua percepção de que vigoraria no interior dos escritos de Deleuze-Guattari uma prosa poética que deve ser dramatizada assim o denota. Para a autora, devemos ler os pensadores franceses com o corpo inteiro, tal qual se faz com uma poesia. A literalidade, 
por conseguinte, envolveria uma dramatização do escrito. $\mathrm{O}$ som, a palavra, a respiração, o fôlego, as limitações etc., são convocados pelo texto, a fim de possibilitar um outro uso deste $^{9}$. Os novos sentidos não estão tanto na proposição, na conexão estabelecida pelo autor, mas no uso ou no modo como a dramatizamos. Desse modo, afirma Malufe (2012):

uma escrita poética em Deleuze seria uma escrita que propõe, no lugar da lógica da metáfora, uma lógica do literal; é aquele que sugere uma leitura literal. E talvez pudéssemos defini-la deste modo: uma escrita ao rés do real, inscrição direta nos corpos. [...] A escrita é um corpo entre outros corpos, em interação afetiva com a criação de mundos que, a todo tempo e a cada instante, nos constitui. (p. 202).

Para a autora, a lógica do literal passaria também pela dramatização de um escrito e implicaria em um outro uso do texto. Não obstante tal leitura faça avançar o debate iniciado por Zourabichvili, ele resta refém das mesmas aporias presentes neste, pois a autora ainda defende a necessidade de uma crença. Só podemos crer nas inferências deleuzeguattarianas caso compreendamos o que significa um "modo de escrita imanente" e, mesmo, uma "prosa poética". Por esse motivo, ainda não nos possibilita pensarmos o texto totalmente em termos de fluxo. Haveria uma imanência de fato, possibilitada por uma parada analítica, mas não de direito. Entretanto, a dramatização do escrito abre uma senda interessante para pensarmos um modo de acessar o fluxo do texto deleuze-guattariano.

\footnotetext{
${ }^{9}$ Emergiria, dessa leitura, alguns pontos de contato com a filosofia de Henri Bergson, autor que defendeu a importância da leitura em voz alta, respeitando os intervalos e respiros propostos pelo autor. Lembramos ainda que, como o nota Alessandro Carvalho Sales (2014), o método da dramatização, trabalhado e apresentado por Deleuze no artigo La méthode de dramatisation, de 1967, foi elaborado sob forte influência do pensamento de Bergson.
} 
Doravante, podemos pensar em uma literalidade envolvendo uma dramatização do escrito, uma coincidência de corpos - o do leitor com o do texto lido - sem necessidade de recorrer a qualquer apriorismo. Nesse sentido, afirmamos novamente, Bergson teria muito a contribuir com esse debate. Encontramos nesse autor algo próximo do método de dramatização entrevisto por Deleuze muitos anos depois:

Antes da intelecção propriamente dita, há a percepção da estrutura e do movimento; há, na página que se lê, a pontuação e o ritmo. Marcá-los como se deve, levar em conta relações temporais entre as diversas frases do parágrafo e os diversos membros da frase, seguir sem interrupção o crescendo do sentimento e do pensamento até o ponto que é musicalmente anotado como culminante, nisso consiste, em primeiro lugar, a arte da dicção. Erra-se ao tratá-la como arte de adorno. Ao invés de chegar no fim dos estudos, como um ornamento, deveria estar no início e por toda a parte, como um sustentáculo. (Bergson, 2006, p.97-98).

No excerto em questão, encontramos muitos pontos de contato com aquilo discutido até o presente momento. A dicção, capaz de nos fazer acessar musicalmente o crescendo do sentimento e do pensamento de um autor, parece coincidir com a boa maneira de ler proposta por Deleuze e com a necessidade de se calar a lógica. Não seria a dicção um exemplo de - ou a própria - dramatização?

\section{BERgSON: UMA VIA PARA PENSARMOS O PAPEL DA METÁFORA NA FILOSOFIA}

Em A Evolução Criadora, Henri Bergson (2005) chegou a asseverar: "O pensamento mais vivo congelar-se-á na fórmula que o exprime. A palavra volta-se contra a ideia. A letra mata o espírito" (p. 138). Embora retirado de seu contexto ori- 
ginal, essa curta assertiva possibilita-nos pensar um tema caro ao pensador francês, qual seja: as limitações da dita linguagem abstrata ou científica para descrever ou acessar certos movimentos vitais. Um fluxo de pensamento, a duração da consciência e a mobilidade do real não seriam passíveis de serem expressos em fórmulas rígidas. Como contornar esse problema? Como levar para dentro do conceito, inerte, um pouco de vida?

Essas questões, postas por Bergson há muito, ressoam na filosofia de Deleuze e, talvez, auxiliar-nos-ão a pensar o debate em torno da literalidade sob outras bases. Lembremos que o autor de O que é a Filosofia? vislumbrou em Bergson um interlocutor importante, por permitir-lhe acessar a tarefa positiva da filosofia e, além disso, por possibilitar-lhe afirmar a supremacia da diferença. Diz-nos Deleuze (2012):

Se a filosofia tem uma relação positiva e direta com as coisas, isso somente ocorre à medida que ela pretende apreender a coisa mesma a partir daquilo que tal coisa é, em sua diferença a respeito de tudo aquilo que não é ela, ou seja, em sua diferença interna. (p. 120).

Muitas das críticas deleuzeanas dirigidas à Platão, Kant e Hegel seguem a picada aberta por Bergson, em seu esforço para desemaranhar as falsas tramas nas quais a filosofia viuse intrincada. Em outros termos, na ânsia bergsoniana por afastar os falsos problemas que tanto afligem a filosofia. $\mathrm{O}$ autor de A Evolução Criadora recusou a dialética e buscou fazer uma crítica da crítica kantiana, nadando contra a corrente de sua época e colocando-se ao lado de uma tradição filosófica francesa marcada pela inventividade. Desse modo, não seria descabido afirmar que, se há uma criação filosófica original na França, tal qual defende Bergson (2006a), Deleu- 
ze prossegue essa tradição, reinventando-a a seu modo. Para os fins desse trabalho, interessa-nos pensar a importância da metáfora e de outras ferramentas da linguagem imagética para a revitalização de um conceito ou de uma proposição filosófica e como isso ressoa nos escritos deleuzeanos e deleuze-guattarianos.

Desde Ensaios sobre os dados imediatos da consciência (1889) até suas últimas obras, como As duas fontes da moral e da religião (1932), Bergson manteve uma posição crítica em relação a certas construções conceituais. Rígidos, muitos dos conceitos filosóficos seriam incapazes de dar conta da mobilidade do real, ou, retomando as análises bergsonianas mais clássicas, dizer da duração interior. Seus escritos, de uma maneira geral, buscaram deslegitimar certa pretensão da filosofia em acessar um absoluto ou expressar os universais a partir de conceitos, produtos estes de uma razão analítica. Por qual razão? Para Bergson (2006):

... um absoluto só poderia ser dado numa intuição, ao passo que todo o resto é da alçada da análise. Chamamos aqui de intuição a simpatia pela qual nos transportamos para o interior de um objeto para coincidir com aquilo que ele tem de único e, por conseguinte, de inexprimível. Pelo contrário, a análise é a operação que reconduz o objeto a elementos já conhecidos, isto é, a elementos comuns a esse objeto e a outros. Analisar consiste, portanto, em exprimir uma coisa em função daquilo que não é ela. Toda análise é assim uma tradução, um desenvolvimento em símbolos, uma representação tomada de pontos de vista sucessivos a partir dos quais anotamos a cada vez um novo contato entre o objeto novo, que estudamos, e outros, que acreditamos já conhecer. Em seu desejo eternamente insaciado de abarcar o objeto que ela está condenada a rodear, a análise multiplica incessantemente os pontos de vista para completar a representação sempre incompleta, varia sem descanso os símbolos para perfazer a tradução sempre imperfeita. Prolonga-se portanto ao infinito. Mas a intuição, se ela é possível, é um ato simples. (p. 187). 
O autor defronta-se com a questão do inexprimível, aquilo vislumbrado em um lampejo por meio de uma intuição, esse ato simples ${ }^{10}$. Os conceitos, mesmo aqueles "excessivamente simples", não seriam nada além de símbolos substitutos de um objeto, utilizados na ânsia por explicar aquela efêmera sensação provocada por uma intuição primeira. Promoveriam uma recomposição artificial do objeto, ao atribuir-lhe algumas características gerais. Representariam, em suma.

Para Bergson (2006), um conceito cujo desígnio fosse exprimir um absoluto, deveria coincidir com este. Precisaria ser único, talhado na exata medida do objeto nomeado. Não seria possível transpô-lo para denominação de um outro objeto, por mais que reconhecêssemos afinidades entre ambos. Qualquer generalização, ou mesmo explicação analítica posterior, acabaria comprometendo essa coincidência conceitual. Conceitos desse porte, podemos inferir, só seriam passíveis de criação por meio da intuição, definida no excerto supracitado como a simpatia pela qual nos transportamos para o interior de um objeto para coincidir com aquilo que ele tem de único.

Provavelmente, muitos dos problemas enfrentados pela filosofia talvez decorram da busca, por parte de um filósofo, em tornar palatável a um leitor uma noção recém-cunhada, acabando assim por perder a sua intuição originária - Bergson (2006) reconhece que todas as filosofias possuem um

\footnotetext{
${ }^{10}$ Deleuze nos lembra que "Bergson apresenta frequentemente a intuição como um ato simples. Mas, segundo ele, a simplicidade não exclui uma multiplicidade qualitativa e virtual, direções diversas nas quais ela se atualiza. Neste sentido, a intuição implica uma pluralidade de acepções, pontos de vista múltiplos irredutíveis" (Deleuze, 2012, p. 10).
} 
lastro intuitivo. A filosofia de sua época floresceu sob a sombra do claro e distinto cartesiano. Um conceito obscuro, inapreensível à primeira leitura, deve ser decomposto e analisado em todas as suas partes, até que não reste nenhuma dúvida acerca de seus componentes constitutivos. Nesse processo, perde-se o pensamento vivo. Guardadas as devidas proporções, seria como se o leitor de um poema buscasse a significação nas letras que o compõem, acreditando que "ao considerar um número crescente de letras agarraríamos por fim a significação que foge", sem atentar para o fato de que as letras "não são parte da coisa, são elementos do símbolo" (Bergson, 2006, p. 211). O poema, contudo, não precisa ser decomposto para ser sentido, apenas talvez para ser compreendido, analisado. Aqui, veríamos a palavra voltar-se contra a ideia. Em filosofia, para Bergson ao menos, ocorreria algo similar.

A confusão entre esse ponto de vista da intuição e aquele da análise, responsável por decompor o mundo em conceitos, teria gerado as pelejas filosóficas entre escolas diversas - empirismo x racionalismo, por exemplo. Isso não significa que os conceitos frutos da razão analítica sejam destituídos de função, pelo contrário. Bergson constantemente lembra-nos que a inteligência visa sempre o viver ${ }^{11}$. Um conceito, tal qual uma fotografia, propiciaria um ponto fixo sobre o qual poderíamos interagir empiricamente, cal-

\footnotetext{
${ }^{11}$ Em As duas fontes da moral e da religião, Bergson (1978) comenta: "Antes de filosofar é preciso viver. Cientistas e filósofos são muito levados a crer que o pensamento se exerce em todos como neles, por prazer. A verdade é que o pensamento visa à ação, e que, se encontramos realmente entre os não-civilizados alguma filosofia, esta deve ser exercida mais que pensada; ela está implicada num conjunto completo de operações úteis, ou julgadas como tais; não se desvincula delas, não exprime por palavras - necessariamente vagas, aliás - senão por comodidade da ação" (p. 137).
} 
cular qual ação mais adequada para extrair de um objeto aquilo que nos convém. Desse modo:

Conhecer uma realidade, no sentido usual da palavra "conhecer", é tomar conceitos já prontos, dosá-los e combiná-los entre si até obter um equivalente prático do real. Mas não se deve esquecer que o trabalho normal da inteligência está longe de ser um trabalho desinteressado. [...] Experimentar um conceito num objeto é perguntar ao objeto o que devemos fazer com ele, o que ele pode fazer por nós. Colar sobre um objeto a etiqueta de um conceito é marcar em termos precisos o gênero de ação ou de atitude que o objeto deverá nos sugerir. (Bergson, 2006, p.206).

Em resumo, a fixidez conceitual, embora não possa reconstituir a mobilidade do real, possibilita-nos decompô-la em instantes estáticos, a fim de que possamos avaliá-los e agir sobre os mesmos visando certos fins práticos. Esse método, científico por excelência, foi transposto para a filosofia e acabou por gerar as muitas confusões denunciadas por Bergson. Como escapar dessas pelejas e acessar intuitivamente o real? Ou, em outros termos, como produzir uma intuição filosófica? Em certa altura do texto A intuição filosófica, publicado entre nós no livro $O$ pensamento e o movente, seu autor coloca-nos uma questão similar:

Podemos nós recuperar essa intuição ela própria? Só temos dois meios de expressão, o conceito e a imagem. É em conceitos que o sistema se desenvolve; é numa imagem que ele se contrai quando o rebatemos na direção da intuição da qual ele desce: mas se quisermos ultrapassar a imagem remontando mais alto que ela, necessariamente recairemos em conceitos e em conceitos mais vagos, mais gerais ainda do que aqueles dos quais havíamos partido à procura da imagem e da intuição. [...] Atenhamo-nos a essas fórmulas, uma vez que não podemos encontrar coisa melhor, mas procuremos pôr nelas um pouco de vida. Tomemos tudo o que o filósofo escreveu, façamos essas ideias espalhadas subir de volta em direção à imagem de onde haviam descido, ergamo-las, já encerradas na imagem, até à 
fórmula abstrata que irá se inflar com a imagem e com as ideias, aferremo-nos então a essa fórmula e vejamo-la, ela tão simples, simplificar-se mais ainda, tanto mais simples quanto maior for o número de coisas que tivermos empurrado nela, ergamo-nos por fim com ela, subamos em direção ao ponto no qual se contrairia em tensão tudo o que estava dado em extensão na doutrina: conseguiremos, dessa vez, nos representar o modo pelo qual desse centro de força, aliás inacessível, parte a impulsão que dá o elã, isto é, a própria intuição. (Bergson, 2006, p.138-9).

Necessariamente temos de expressar o pensamento vivo que intuímos em palavras, utilizando-nos de fórmulas para tanto, e estas acabam sempre por cristalizar aquela intuição primeira. Não obstante isso, resta-nos sempre uma imagem, por vezes uma metáfora. Conceitos e imagens são nossas únicas ferramentas de comunicação e, a seu modo, se complementam. Longe das fronteiras estabelecidas pela linguagem abstrata, Bergson reconhece a importância das imagens em filosofia, apresentadas como o ponto a partir do qual os conceitos tornam-se possíveis. A imagem, por conseguinte, seria aquilo mais próximo de uma intuição. Ao invés de rechaçar uma metáfora, o filósofo defende o seu valor para reconstituição de uma intuição fundacional, deveríamos partir do conceito para a imagem que o origina, para assim nos aproximarmos daquela intuição primeira.

Retomemos, sem preconceitos, a metáfora "o cérebro é muito mais uma erva do que uma árvore". Não devemos interpretar tal enunciado a luz do que foi escrito alhures por Deleuze e Guattari, mas buscar acessar a intuição que the originou. Pois, nessa imagem apresentada por DeleuzeGuattari encontra-se, contraída, todo o vitalismo dado em extensão na sua obra. Jamais conseguiremos acessar o centro de força dessa imagem, seu elã vital ou a intuição dos 
autores adequadamente, mas podemos sentir a potência que lhe originou. Para tanto, antes de retornarmos ao enunciado a fim de interpretá-lo sem qualquer apelo ao metafórico, não precisamos crer no autor, acreditar em sua afirmação de que aquilo que ele acabou de dizer, embora soe metafórico, não é uma metáfora. Antes, devemos seguir o texto, sem recuo de nenhuma ordem - seguir um texto sem interrupção, conforme a arte de dicção bergsoniana -, dramatizando-o. Seguir, apenas. Até que a força dos escritos deleuzeanos e/ou deleuze-guattarianos atinja-nos em toda a sua potência

Ao fim, se há ou não metáfora em Deleuze e Guattari, isso pouco importa. Essa é uma falsa questão. Há uma escrita densa, carregada de imagens, paradoxos e, também, metáforas. Perdemos o fluxo de sua escrita, sua prosa poética, ao pararmos para analisar as letras que a compõe, seus elementos constitutivos. Essa análise pormenorizada impedenos de acessar a intuição dos autores, dramatizar o escrito que temos em mãos. A compreensão da falsa questão na qual o debate sobre a literalidade está assentado, contudo, só emerge a partir desse desvio pelo pensamento de Bergson. Resta-nos, agora, pensar as implicações dessa nossa leitura para aquela dita teoria do ensino deleuzeana vislumbrada por Zourabichvili (2005).

\section{CONSIDERAÇÕES FINAIS: UMA TEORIA DO ENSINO DELEUZEANA?}

A pretensa teoria do ensino deleuzeana defendida por François Zourabichvili (2005) estaria assentada sobre três premissas básicas, quais sejam: 1) ensina-se sobre o que se 
pesquisa e não sobre o que se sabe; 2) não se sabe como alguém se torna bom naquilo que é, quais signos o tornam apto a desenvolver uma atividade; e, por fim, 3) a atividade do pensar não diz respeito à busca pelas soluções, mas envolve uma gestão dos problemas. Modificar-se-ia, desse modo, certas balizas da pedagógica clássica. A relação entre mestre e aprendiz, por exemplo, deixaria de ser pautada por uma falta fundante. O saber, aquele conjunto de conhecimentos que em tese faltariam ao aprendiz, não figuraria mais como a base dessa relação, cedendo lugar para o ato de pesquisar. $\mathrm{O}$ processo do aprender ou a busca empreendida pelo aprendiz, a pesquisa em si, tornar-se-ia mais importante do que a aquisição ou a compreensão de conhecimentos previamente formatados. A recorrente preocupação com metodologias ou outras técnicas utilizadas para se ensinar algo a alguém também passaria a carecer de finalidade, uma vez que jamais saberemos quais os signos tornam uma pessoa apta a desenvolver algum tipo de atividade ou a aprender algo que até então lhe era desconhecido. Aprender, por fim, não significaria encontrar respostas a problemas dados, mas sim adentrar em um processo de criação dos próprios problemas. Trata-se, pois, de uma "experiência que envolve todo o ser” (Zourabichvili, 2005, p. 1310).

A pretensa teoria do ensino vislumbrada por Zourabichvili, desse modo, afirmaria a proeminência do fazer em relação ao saber. O processo de aprendizado seria mais significativo e importante do que a aquisição de um saber pronto, e, assim, qualquer coisa que não advenha do próprio processo - metodologias, problemas já formatos e assim por diante - perderia relevância. Essas balizas, nos dizeres de Zourabichvili (2005), estariam operando no inte- 
rior da própria obra deleuzeana e/ou deleuzo-guattariana. Os livros escritos por Deleuze e Deleuze-Guattari não procurariam informar ou partilhar com o seu leitor um determinado conjunto de conhecimentos/reflexões, mas, imbuídos dessa concepção pedagógica, buscariam servir como signos capazes de ofertar e/ou provocar uma experiência de pensamento singular. Para tanto, os autores não deveriam ser confundidos com mestres e tampouco suas obras não deveriam funcionar como grade de leitura do mundo. Obras como O Anti-Édipo e Mil Platôs não funcionariam como manuais de conduta e tampouco serviriam como metáforas explicativas do real, antes seriam espécies de provocadores. Para funcionarem, o leitor deveria apenas crer naquilo que lhe é descrito nessas obras, realizando uma leitura literal. Não é por outro motivo que, tal qual argumenta Zourabichvili (2005), a literalidade necessita ser compreendida como uma "pedagogia interna à filosofia" (p. 1311).

A literalidade seria a base da crença, pois envolveria uma aceitação plena daquilo transcrito no papel. Por meio dela, o leitor poderia acessar o processo de pensamento de Deleuze e Deleuze-Guattari, vislumbrando os modos como os autores constroem seus problemas em ato e acessar assim o processo de pensamento deleuzeano e deleuzoguattariano. Cada formulação, cada enunciado, emergiria de acordo com os fluxos, ou as marés, nas quais Deleuze e Guattari navegaram e poderiam guiar o leitor para outros mares. O famoso exemplo dado por Deleuze, retirado de Bergson (2005) aliás, e retomado por Zourabichvili (2005) para ilustrar seu argumento, diz respeito ao aprendiz de natação. Retomemo-lo, pois: 
O movimento do nadador não se assemelha ao movimento da onda; e, precisamente, os movimentos do professor de natação, movimentos que reproduzimos na areia, nada são em relação aos movimentos da onda, movimentos que só aprendemos a prever quando os apreendemos praticamente como signos. Eis porque é tão difícil dizer como alguém aprende: há uma familiaridade prática, inata ou adquirida, com os signos, que faz de toda educação alguma coisa amorosa, mas também mortal. (Deleuze, 1988, p. 31).

Sem querer adentrar na discussão acerca dos signos algo que demandaria outro trabalho, dado sua densidade -, percebemos a importância da literalidade para essa teoria da aprendizagem deleuzeana proposta por Zourabichvili. Aprender com o texto deleuzeano e/ou deleuze-guattariano envolveria uma sensório-motricidade, como defendeu o próprio Deleuze (1988), ou seja, não uma imitação de certos pressupostos erigidos no interior da filosofia dos autores de Capitalismo $\mathcal{E}$ Esquizofrenia, mas uma conjugação de nossos corpos com os seus pontos relevantes, tal qual o de um neófito que se lança ao mar a fim de aprender a nadar, conjugando os pontos de seu corpo com os da onda. Literalidade como dramatização, como bem o notou Anita Costa Malufe (2012).

O leitor-aprendiz seria aquele que crê, aceitando os movimentos próprios ao texto e permitindo-se conectar aos pontos que mais o afetam. Essa experiência implicaria um real aprendizado, pois, ainda seguindo Zourabichvili (2005), aquele que adentra nesse processo transmuta sua crença em uma espécie de ação sobre si, em um fazer, capaz de disparar outras experimentações de pensamento.

Embora consistente, a leitura proposta por Zourabichvili fraqueja ao não conseguir explicar a exacerbada utilização de metáforas por parte de Deleuze e Guattari. Como notou 
Tomaz Tadeu (2005), embora a teoria de ensino tal qual apresentada pelo comentador consiga explicar muito dos intentos pedagógicos de Deleuze e Deleuze-Guattari bem como a ânsia dos autores em fomentar experimentações de pensamento mais do que interpretações, ela não é capaz de explicar os abundantes recursos metafóricos presentes nos escritos deleuzeanos e deleuzo-guattarianos. Nossa hipótese é que, por conta da importância dada ao conceito de crença, Zourabichvili acabou criando uma contraposição, literalidade versus metafórico, que, longe de neutralizar o uso de metáforas por parte de Deleuze e Deleuze-Guattari, acabou lhe dando maior importância. A literalidade em Zourabichvili, não seria descabido dizer, surge como uma espécie de ferramenta, ou metodologia, capaz de permitir ao leitor acessar o processo de pensamento presentes em obras como O Anti-Édipo. Ora, a pretensa teoria do ensino deleuzeana apresentada por Zourabichvili nega a necessidade de qualquer metodologia e, nesse sentido, a fé cega na literalidade pode surgir como um grande paradoxo.

Retomar, contudo, a discussão sobre literalidade a partir de Henri Bergson e assumindo a sua influência na filosofia de Deleuze e Deleuze-Guattari nos possibilita ultrapassar essa aporia. $\mathrm{O}$ uso ou não de metáforas, o quanto estas impedem ou não a função pedagógica presente nos textos deleuzeanos e deleuzo-guattarianos, surge como um falso problema. Deslocar o debate sobre a literalidade para um diapasão bergsoniano, abicando assim do conceito humeano de crença, permite-nos resgatar a teoria de ensino preconizada por Zourabichvili sem as aporias apontadas por Tomaz Tadeu e concedendo aos recursos metafóricos um outro estatuto. A dramatização ganharia, ademais, um lugar 
de destaque.

Para encerrar, convém apenas lembrar que Deleuze e Guattari (1992) não negaram a importância de abstrações e ficções para a composição de um plano de imanência filosófico. Imagens, metáforas e outras tantas figuras de linguagem não desprestigiam uma filosofia da imanência. Ao ouvir um texto deleuze-guattariano, devemos contemplar os seus movimentos, suas idas e vindas, sentir as imagens que nos oferecem, ainda que soem metafóricas. Dessa contemplação, quiçá surja a criação como síntese passiva. Afinal, afirmam Deleuze e Guattari: "a sensação é contemplação pura, pois é pela contemplação que se contrai, contemplando-se a si mesma à medida que se contempla os elementos de que se procede. Contemplar é criar, mistério da criação passiva, sensação" (Deleuze; Guattari, 1992, p. 272). Contemplar é fazer, ao invés de crer é fazer como defende Zourabichvili (2005). Seguir o fluxo do texto sem interrupções analíticas, sem explicações que garantam uma imanência de fato, mas não de direito. Dramatizar o escrito deleuze-guattariano naqueles pontos que nos soem como vitais, se metafóricos forem estes, qual o problema? Com Bergson vimos que a metáfora surge como problema somente nos momentos de interrupção, quando da recomposição abstrata do real em conceitos - representação -, mas em outros momentos, mais contemplativos, ela pode auxiliar-nos a resgatar a intuição primeira de uma filosofia - criação. Se há ou não metáfora em Deleuze, isso pouco importa, interessante seria resgatar a intuição de sua filosofia sem recorrer às interrupções analíticas de seus escritos. Contemplar um texto de outro modo, ouvir aquilo que convém, tal qual na definição de aula dada por Deleuze em 
seu abecedário, com a qual encerramos esse trabalho:

Não podemos dizer que tudo convém a todos. As pessoas têm de esperar. Obviamente, tem alguém meio adormecido. Por que ele acorda misteriosamente no momento que lhe diz respeito? Não há uma lei que diz o que diz respeito a alguém. $\mathrm{O}$ assunto de seu interesse é outra coisa. [...] Uma aula é emoção. É tanto emoção quanto inteligência. Sem emoção, não há nada, não há interesse algum. Não é uma questão de entender e ouvir tudo, mas de acordar em tempo de captar o que lhe convém pessoalmente.

Abstract: This article aims to think in the work of Gilles Deleuze especially written with Felix Guattari, the debate involving the literalness issue from a retreat to the thought of the philosopher Henri Bergson. The deleuzeguattarian literalness it's a working way in which certain formulations must being read to the letter (a la letter) rather than interpreted as metaphors, particularly those of imagistic content. The question of literalness was introduced into our country through the dossier Between Deleuze and Education published in 2005 in the journal Education $\mathcal{E}$ Society and fomented a lively discussion, particularly in the educational field - given the fact that François Zourabichvili suggested an alleged deleuzean teaching theory from that notion. Far from wanting to give an end to this debate, we proposed think this question under the aegis of Bergson's thought in order to offer an escape from the established binary.

Keywords: Gilles Deleuze; Literalness; Metaphor; Henri Bergson.

\section{REFERÊNCIAS}

ALLIEZ, Eric. "Sobre o bergsonismo de Deleuze". In: ALLIEZ, Erica (org.). Gilles Deleuze: uma vida filosófica. São Paulo: Editora 34, 2000. p. 245-266.

BERGSON, Henri. As Duas Fontes da Moral e da Religião. Rio de Janeiro: Zahar Editores, 1978.

A Evolução Criadora. São Paulo: Martins Fontes, 2005.

. "A filosofia francesa". In: Trans/Form/Ação, São 
Paulo, vol. 29, n. 2, p. 257-271. 2006a.

. O Pensamento e o Movente. São Paulo: Martins Fontes, 2006.

CORNIBERT, Nicolas; GODDARD, Jean-Christophe (org.). Ateliers sur L'Anti-Oedipe. Paris: Metispresses, 2008.

DELEUZE, Gilles. Bergsonismo. São Paulo: Editora 34, 2012.

. Diferença e Repetição. São Paulo: Graal, 1988.

. Empirismo e Subjetividade. São Paulo: Editora 34, 2001.

. Nietzsche e a Filosofia. Rio de Janeiro: Editora Rio, 1976.

. Spinoza et le problème de l'expression. Paris: Éditions de Minuit, 1968.

DELEUZE, Gilles; GUATTARI, Félix. O Anti-Édipo: capitalismo \& esquizofrenia. São Paulo: Editora 34, 2010.

. Mil Platôs. vol.1. São Paulo: Editora 34, 2000.

. Mil Platôs. vol.3. São Paulo: Editora 34, 2007.

. O que é a Filosofia? São Paulo: Editora 34, 1992.

DELEUZE, Gilles; PARNET, Claire. Diálogos. Lisboa: Relógio D'Água, 2004.

GANDIN, Luís; PARASKEVA, João; HYPOLITO, Álvaro. "Mapeando a [complexa] produção teórica educacional 
- entrevista com Tomaz Tadeu da Silva". In: Currículo sem Fronteiras, n.2, n.1, p.5-14. Jan-jun/2002.

MALUFE, Annita Costa. "Aquém ou além das metáforas: a escrita poética na filosofia de Deleuze". In: Revista de Letras, São Paulo, v. 52, n.2, p. 185-204. Jul/Dez. 2012.

. "Uma poética da imanência: a escrita em Deleuze". In: Acta Scientiarum: Language and Culture, Maringá,v. 37, n.3, p. 233-241. Jul/Set. 2015.

PELBART, Peter Pál. "Solidão, fascismo e literalidade". In: Educação \& Sociedade, Campinas, v. 26, n. 93, p. 1323-1329. Set-Dez. 2005.

SALES, Alessandro Carvalho. Deleuze: pensamento $e$ acordo discordante. São Carlos: EDUFSCAR, 2015.

TADEU, Tomaz. "Deleuze e a questão da literalidade: uma via alternativa". In: Educação \& Sociedade, Campinas, v. 26, n. 93, p. 1331-1338. Set-Dez. 2005.

ZOURABICHVILI, François. "Deleuze e a questão da literalidade". In: Educação \& Sociedade, Campinas, v. 26, n. 93, p. 1309-1321. Set-Dez. 2005.

"L'écriture littérale de L'Anti-Edipe". In: CORNIBERT, Nicolas; GODDARD, Jean-Christophe (org.). Ateliers sur L'Anti-Oedipe. Paris: Metispresses, 2008. p.247-256.

2011.

. La Littéralité et autres essais sur l'art. Paris: PUF, 